\title{
Influence and Intensity of Exogenous Factors on the Development and Stability of Rural Areas
}

\author{
Petra Pártlová ${ }^{1, *}$ \\ ${ }^{1}$ Institute of Technology and Business, Department of Management, Okružní 517/10, 37001 České Budějovice, Czech \\ Republic
}

\begin{abstract}
This contribution focuses on the issue of the influence and intensity of exogenous factors on the development and stability of rural areas. The results are presented at two levels. The first reflects the monitoring of the influence of external factors on the external environment of companies, i.e. those factors which they have limited possibilities to influence, and how to eliminate the potential negative impacts thereof. The second provides information on the results and evaluation of four basic parameters in the field of knowledge skills, namely contenders, competition, coordination and cooperation. The evaluation of the goals set are based on the results of a questionnaire survey, supplemented by controlled interviews with business managers and the managements of local action groups (LAGs) in the Region of South Bohemia. The created database is analysed using the method of content analysis and the simultaneous use of statistical methods. The main outputs of the solution determine the significance and strength of the external environment on companies, which is mostly influenced by competitors, suppliers, customers and business partners. In contrast, universities and research institutes do not have a significant impact on the business environment. Similar results apply to LAGs, where in most cases the LAGs cooperate with each other and are not considered competitors, thereby also reporting good cooperation with towns, micro-regions and the regional authorities of South Bohemia. In contrast, LAGs reported none or poor cooperation with the National Network of LAGs and ministries.
\end{abstract}

Keywords: external factors; companies; LAG; actors; rural areas

\section{Introduction}

Rural development policy at the turn of the $20^{\text {th }}$ and $21^{\text {st }}$ centuries was the subject of harsh criticism, which was followed in 2006 by a relatively strong trend towards a new paradigm of rural areas, as incorporated in a new concept by the OECD [1]. The aim of this concept is primarily the growth of rural competitiveness and to look for the local benefits in an area, on the basis of which financial and non-financial support should be directed. A very important factor in this is that new rural development policies should be relevant to the key actors because they bear the responsibility for all the important activities that strengthen development and stability [2-5].

Rural development policy is very complex because it affects many areas of life of the population, is influenced by the historical and cultural contexts of a region, and its implementation depends to a large extent on the activity and cooperation of the local actors [6,7].

With regards to the issue at hand, it is possible to distinguish three groups of actors in rural areas: a) those who participate and are involved in the process of dealing with rural development (e.g. cooperating municipalities and entrepreneurs); b) actors and entities responsible for a certain activity (e.g. citizens and their associations, visitors, etc.); and c) the affected, i.e. entities in whose area of interest the activity is carried out (e.g. regional authority, administration of a protected landscape area or national park, ministry, etc.) $[8,9]$.

The important actors are the mayors and the representatives of the municipalities, who by the virtue of their position have and should have open access to all the other actors, whereby the bottom-up principle should be applied [10]. Other important actors are ministries, with direct influence on the municipalities for their delegated competence, and within the given laws. Regional authorities may be responsible for all the functions of rural development, from methodically helping and controlling the activities of municipalities through to active

\footnotetext{
* Corresponding Author: partlova@mail.vstecb.cz
} 
participation, with the tools they have at their disposal, to reduce or limit the disparities between municipalities, whilst at the same time, developing their activities across a whole region.

Companies are also important actors. The private sector has great potential for development activities. Their cooperation is based on the principle of profitability. They are willing to support a number of development activities, but expect some form of reciprocity [11]. Although the representatives of local institutions (such as schools and libraries) have little power to solve more fundamental problems within municipalities, there are synergies to be found with other actors [9, 12]. Other actors, who are not mentioned often, are political parties and their relatively small influence on the leadership of small municipalities. However, in certain circumstances, political parties hold the keys to accessing state subsidies. Local action groups (LAGs) are also important actors, bringing together representatives of all groups. LAGs, similar to regional authorities, perform all three functions $[8,9]$. A well-functioning LAG, which wants to make the most of the potential of its territory, applies mainly the features of networking and cooperation [13-15]; it uses new approaches and procedures in guiding the local development of the territory [16].

The intensity of partnerships is one of the factors influencing the direction and intensity of rural development [17]. Important factors influencing the relations and ties in the region include contenders (actors without interaction), competition (interaction arises), coordination (adaptation of actions to avoid conflicts) and cooperation (mutually beneficial partnership, most important for development) [18]. In terms of rural development, a distinction is made between endogenous and exogenous development factors. Endogenous factors are directly linked to the activities of existing rural users, meaning the development actors [8]. Exogenous factors are the external factors representing a certain framework of factors and instruments that affect rural development, whereby individual actors cannot influence them directly (location of the municipality, natural environment, the operation of other regions on the one hand, legislation, financial systems, central development instruments, grantsupported activities, etc. on the other hand [8, 19, 20-23].

The research that forms the basis of this contribution focuses on two levels in terms of the factors of rural development. The first part focuses on an analysis of how external factors influence business activity in the Region of South Bohemia, as well as on the way the intensity of that influence depends on the close surroundings of a company. The second part focuses on local action groups as important actors in the development of rural areas and on the influence of external factors on their activities in terms of cooperation and competition, as well as on how such factors affect their activities in the search for solutions to rural development problems, the implementation of strategy, and the creation of the conditions for further cooperation and networking.

\section{Methodology}

The primary data sources are a questionnaire survey and controlled interviews. In the first part of the research, the influence of the external environment on the development of business activities in the Region of South Bohemia is evaluated. For this purpose an analysis was conducted of the responses of 102 companies operating in rural areas in the region who were contacted and asked to identify the external environmental factors that influence other actors and their business activities. The results of the survey were processed using the statistical method in the R programme and presented graphically. The chosen techniques are considered suitable for primary data collection whenever phenomena cannot be monitored directly.

The second part of the research covers local action groups (16) in the Region of South Bohemia. A questionnaire survey and field research were conducted. The structure of the questionnaire was divided according to the four core areas of research, namely contenders, competition, coordination and cooperation. Under contest, there were four questions with three possible answers (yes, no, no interaction). Under competition, there were three partial questions with possible yes and no answers, as well as a detailed justification thereof. Under coordination, issues aimed at coordinating activities within LAGs themselves are addressed, including the involvement of local actors in the LAGs, such as the municipalities themselves and their mayors. Furthermore, the cooperation of the towns, the regional authority of South Bohemia, and the ministries involved in the activities of the LAGs are addressed. Under cooperation, the LAGs cooperation with the for-profit sector, private sector, National Network of LAGs and South Bohemia Network of LAGs are analysed.

After completing the questionnaire, a field survey was carried out in combination with guided interviews with the representatives of all South Bohemia LAGs in order to complete the missing parts of the questionnaire.

The research material was subjected to content analysis. Content analysis is one of many possible types of qualitative data analysis. Within this context, the coding method was used [24]. All analysed material was divided into four areas in connection with the 15 research questions. Each unit created was coded on the basis of the answers (YES, NO, and in some cases NO RELATION). The application of coding is especially useful when the aim of the research is to describe different views on a given research topic [25]. The research results are presented 
here using the descriptive method. The answers are structured into graphs on the basis of which a detailed analysis and evaluation are carried out.

\section{Results and Discussion}

In principle, a possible tool for the successful management of business activities in regions is a functioning partnership between the private, public and non-profit sectors with the citizens of the region. In rural areas, the cooperation of all interested legal and natural persons with the public authorities is very important. Such cooperation is representative of the whole community in a municipality or region and its essence is the search for and solution of common problems and the achievement of common goals. Such partnerships bring together and multiply the ideas, energy and resources of stakeholders (local people, administrations, entrepreneurs, non-profit organizations, etc.), whereby the quality of the final product depends on it.

\subsection{Analysis of the external business environment}

The performed analysis shows that companies and their activities are affected by many actors with varying degrees of intensity (see Table 1 and Figure 1). The influence of competitors, suppliers, customers and business partners were identified as being significant to very significant. The companies operating in rural areas also show that associations (such as LAGs) and financial institutions have a large influence. On the contrary, universities, local government, government, political parties and the media have little to no influence. Research institutes and academies of sciences have the least influence on the activities of the companies.

Table 1. Influence of actors in rural areas on companies

\begin{tabular}{|l|c|c|c|c|c|}
\hline Actors in rural areas & $\begin{array}{c}\text { No } \\
\text { influence }\end{array}$ & $\begin{array}{c}\text { Little } \\
\text { influence }\end{array}$ & $\begin{array}{c}\text { Significant } \\
\text { influence }\end{array}$ & $\begin{array}{c}\text { Very } \\
\text { significant } \\
\text { influence }\end{array}$ & Total \\
\hline \hline Competitors & 11 & 21 & 50 & 20 & 102 \\
\hline Suppliers & 11 & 28 & 48 & 15 & 102 \\
\hline Customers & 8 & 15 & 32 & 47 & 102 \\
\hline Distributors & 26 & 29 & 36 & 11 & 102 \\
\hline Business Partners & 20 & 16 & 41 & 25 & 102 \\
\hline Financial institutions & 24 & 30 & 38 & 10 & 102 \\
\hline Universities & 58 & 29 & 13 & 2 & 102 \\
\hline $\begin{array}{l}\text { Research institutes, } \\
\text { academies of sciences }\end{array}$ & 68 & 26 & 8 & 0 & 102 \\
\hline $\begin{array}{l}\text { Local government and } \\
\text { self-government }\end{array}$ & 42 & 38 & 15 & 7 & 102 \\
\hline Political parties & 64 & 20 & 11 & 7 & 102 \\
\hline Government & 59 & 18 & 18 & 7 & 102 \\
\hline Average & 53 & 30 & 16 & 3 & 102 \\
\hline Associations (LAGs) & 24 & 26 & 20 & 32 & 102 \\
\hline
\end{tabular}

Source: Authors. 


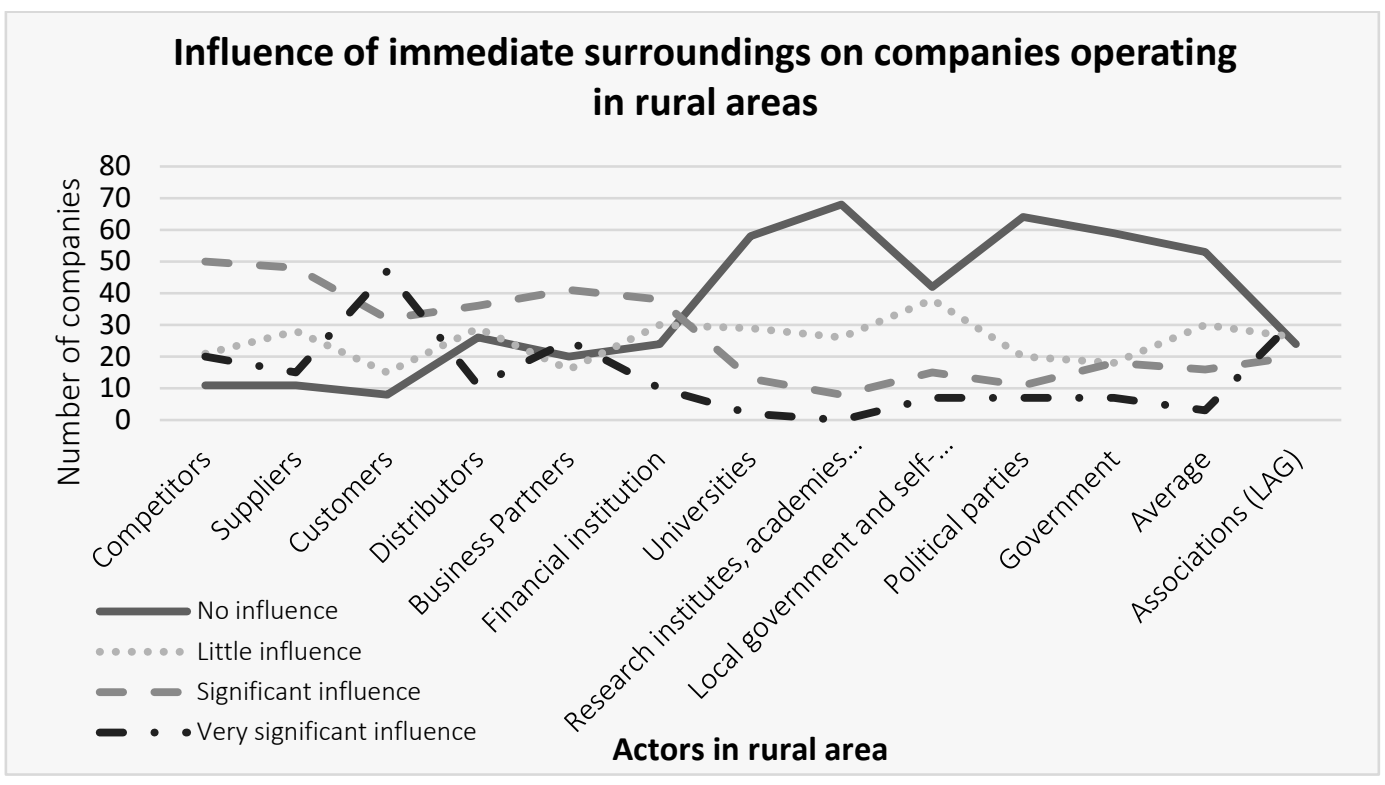

Figure 1. Influence of immediate surroundings on companies operating in rural areas

Source: Authors.

The significance of the intensity of influences on the factors was determined using the R programme.

Calculation:

$$
\begin{aligned}
& \begin{array}{lrrr}
P \text { value } \quad 2.2 E-16 & x 2 & 133.2868
\end{array} \\
& V \quad 0.568091803 \text { freedom line-1 } x \text { column }-1
\end{aligned}
$$

Statistical methods were used for the analysis, proving that the intensity of the influence depends on the close surroundings of the enterprise ( $\mathrm{P}$ value $=2.2 \mathrm{E}-16, \alpha=0.05)$. The hypothesis was confirmed. Based on the results, $\mathrm{V}=0.5681$, it is possible to deduce a medium degree of statistical dependence.

Based on the results, it is possible to infer the willingness of companies to cooperate with partners and subjects in the business environment. It is clear that, as far as the other actors in rural areas are concerned, no higher consensus is to be found in the search for such cooperation. Nevertheless, certain forms of partnership are offered, which are cooperation with institutions for business support, cooperation in the field of education, cooperation between companies, with the regions and municipalities.

With regards to the cooperation with institutions and agencies established by ministries (CzechInvest, CzechTrade, ČMZRB, EGAP, chambers of commerce, Society of Science and Technology Parks, unions, associations, regional development agencies, regional advisory and information centres), this is considered to be rather wide ranging. Forms include technical parks, centres, incubators, investment in industrial zones, use of brownfield sites, organizing foreign missions to exhibitions and fairs, etc.

Another possible way is cooperation with research institutions (public and state universities, public research institutions, and private innovation enterprises), which are seen to provide the opportunity to cooperate on research activities, both basic and applied. Innovation vouchers are also a form of cooperation, which is a form of counselling, including expert and support services, especially for SMEs.

A very important form of cooperation, as evidenced by the previous figure, is the cooperation between companies. Companies associate with one another through business networks (networking) and clusters. Such clusters allow companies to react flexibly enough to adapt to the increased speed of technological change and the rapidly growing competitiveness required in global markets.

Cooperation between the region and the business sector is based on a certain form of participation, the main task of which is the creation of conceptual documents, participation in specific development activities or the creation of public alliances (such as public-private partnerships (PPP)). The aim of such cooperation is to support the development of innovation with a suitable infrastructure.

The last type of cooperation that has influenced the development of rural areas in the last 15 years is the active role of LAGs. LASGs have several roles and carry out many activities in rural areas. LAGs are actively involved in improving the cooperation of all entities in municipalities (municipal authorities, entrepreneurs, non-profit organizations, citizens). Even their form predestines them to influence all actors and help them to overcome 
isolation and offer such activities that lead to mutual cooperation. LAGs also ensure an integrated approach to rural development, using the specificities and assumptions of a particular rural area.

\subsection{Analysis of LAG cooperation factors}

\section{Contenders}

As revealed by the results (see Figure 2), LAGs do not contend with others. On the contrary, most of them cooperate on projects, strategy development, sharing knowledge, based on the principle of collegiality. LAGs are linked by the common nature of their activities.

The same applies for the second question, which deals with LAG cooperation throughout the Czech Republic. The LAGs mostly cooperate and share information about their activities. However, the relations are no longer as intense as in the case of the regional LAG network. They point out that they are mostly united by the Leader method, which is now applied through community-led local development (CCLD).

Another question was related to the competition of foreign LAGs. Most South Bohemian LAGs do not consider their foreign partners to be rivals, or they have no relation with them and have not considered participating in any cross-border cooperation. The reason for this is the allocation of only small financial funds for such projects.

The last question focused on the possible competition between public administrations and LAGs. Most LAGs perceive public administration on the basis of cooperation. They agree that public administrations have financial resources at their disposal, which they might allocate to local action groups for ongoing projects.

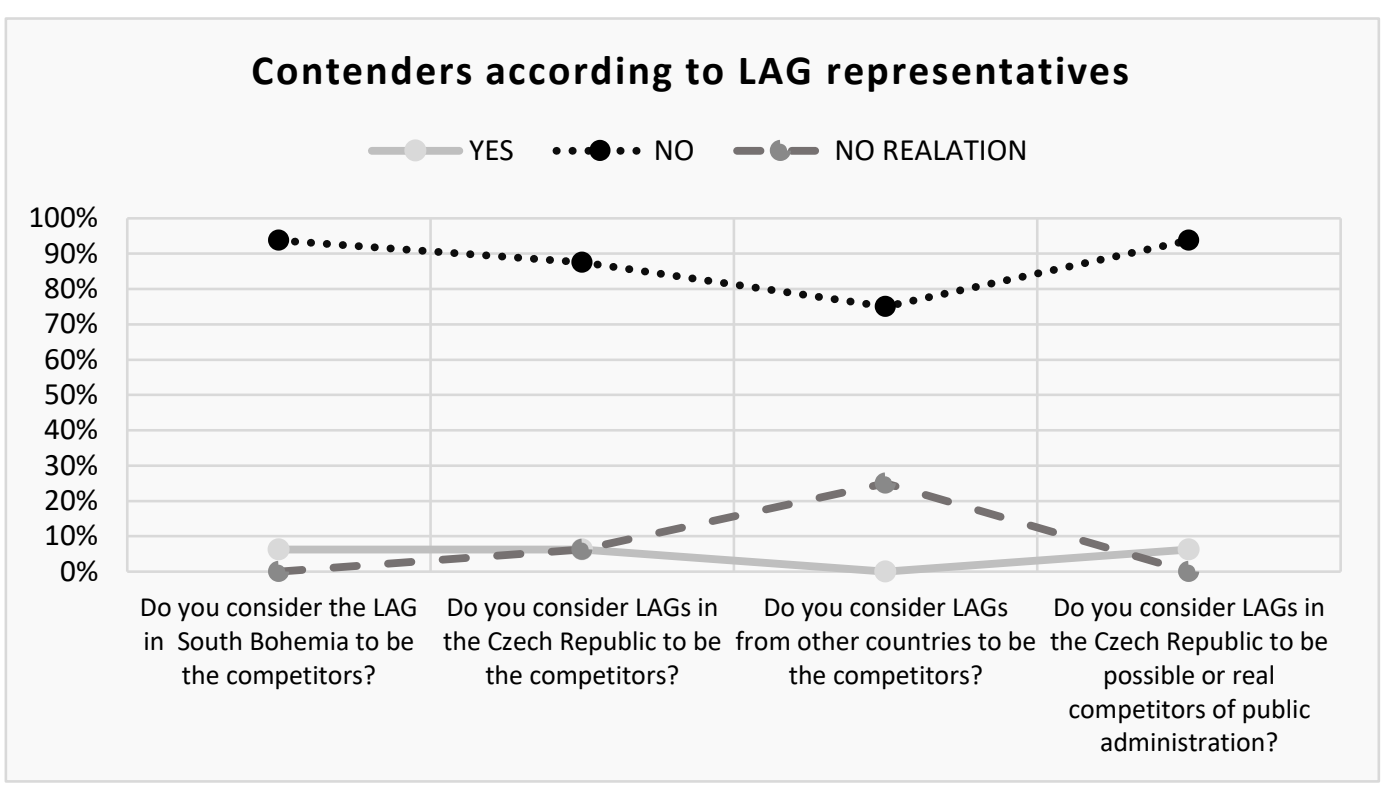

Figure 2. Contenders according to LAG representatives

Source: Authors.

\section{Competition}

Under competition, three areas were monitored (see Figure 3). More than two-thirds of the LAGs consider other LAGs to be their allies. They agree that more successful LAGs actually support other local groups and that they create a good image in the Region of South Bohemia. LAGs are not economic entities, so it is much more favourable to use examples of good practice than healthy competition. At the same time, they point out that each LAG has its own territory, its own needs, where it implements projects.

The second question sought to determine whether some form of LAG evaluation should be created. The majority answered that each LAG has its own specifics and that it is very difficult to find the right key with which to evaluate different LAGs. However, many of them added that the evaluation of LAGs would help to point out the less active LAGs and, under certain conditions, would act as a motivational factor. When asked the last question, i.e. whether LAGs should receive financial resources equally, the vast majority of LAGs agreed that it is necessary to respect the territory, its size, population and even the development of the region. 


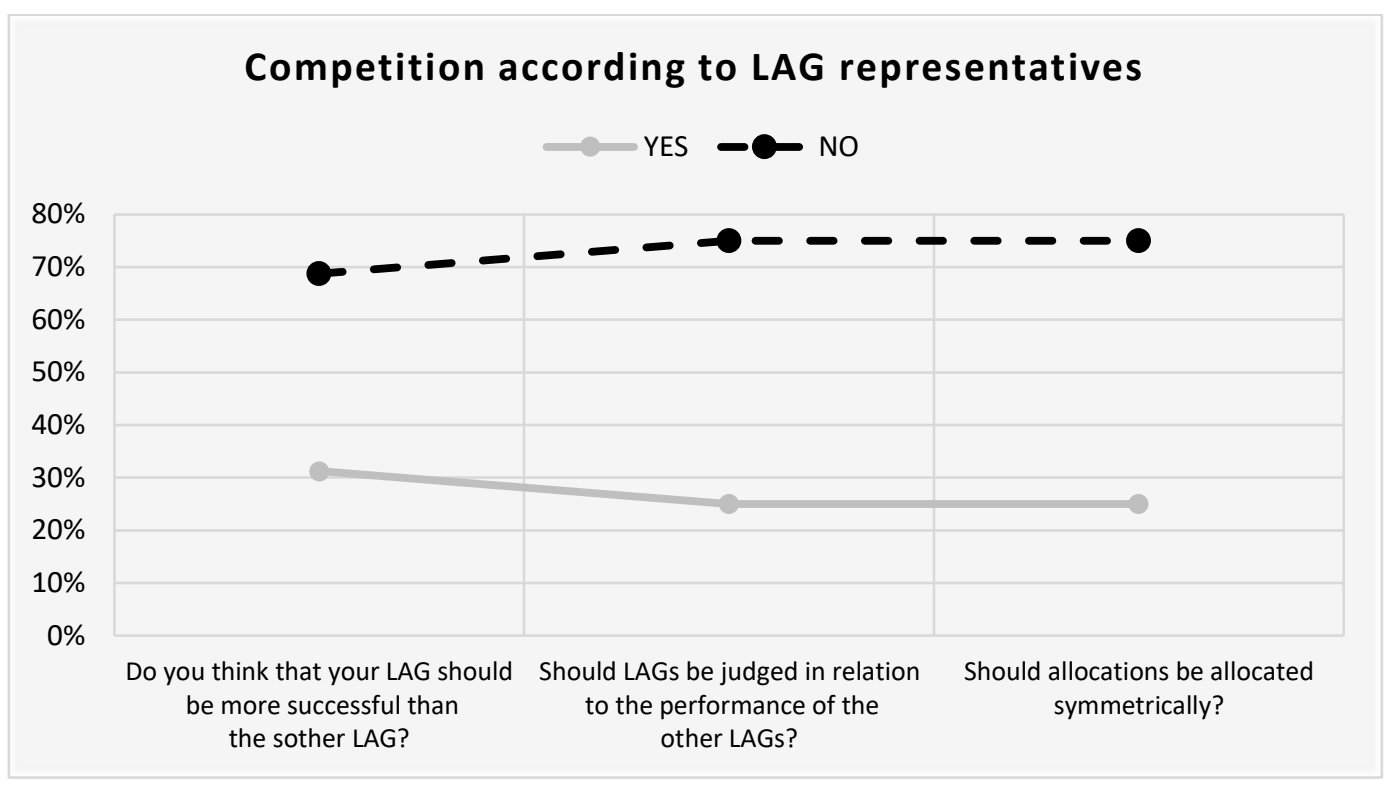

Figure 3. Competition according to LAG representatives

Source: Authors.

\section{Coordination}

Under coordination, the questions focused on the cooperation between LAGs and other actors.

With regards to the cooperation between municipalities and LAGs, most municipalities do not cooperate with LAGs. One of the reasons why this is the case is that so far, the municipalities do not have enough information on what the LAGs can offer the municipalities. A change in attitude among municipalities may be instigated over the long-term if LAGs showed more proactive behaviour towards them. Communication with the municipalities takes place mostly through email and telephone communication, and through municipal dailies; personal meetings proved to be the most effective. However, about one-third of the LAGs evaluated the cooperation with municipalities as being very good, and with towns, micro-regions and the regional authority of South Bohemia as good. All the LAGs agreed that the cooperation with the ministry is rather poor. The LAGs would highly appreciate it if the whole system became clearer and simplified (the setup of departments). The results are presented in Figure 4.

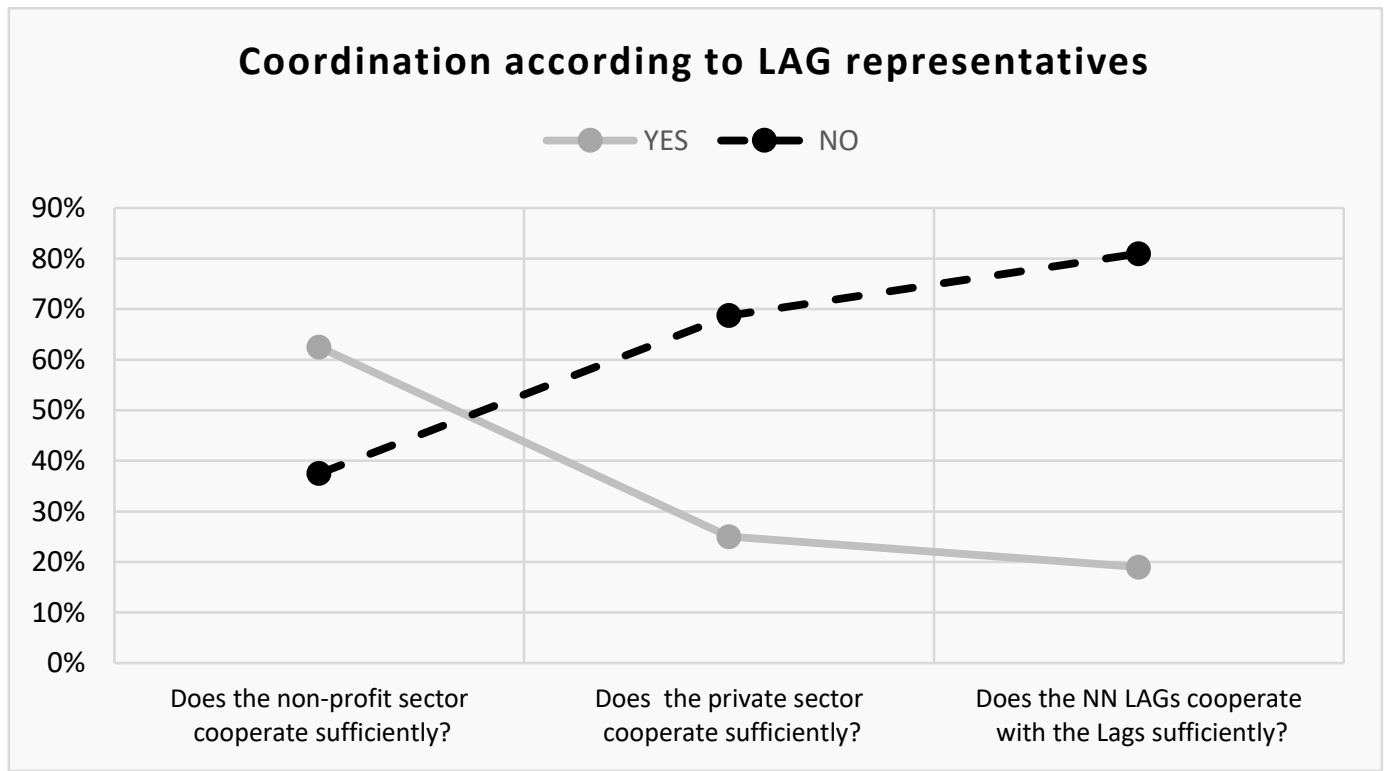

Figure 4. Coordination according to LAG representatives

Source: Authors. 


\section{Cooperation}

Under cooperation (see Figure 5), the focus was on partnership with the non-profit sector, private sector and the National Network of LAGs. With regards to the first two, the opinion of the majority is that if the LAG is active and has something to offer, the cooperation works well. The situation has improved significantly, especially in the for-profit sector, with a change in the subsidy policy and the redistribution of the activities into more areas. In the private sector, cooperation with the agricultural sector has been excellent for a long time. With other SMEs the cooperation is worse, but even here, with the new subsidy policy, things are improving. As for the partnership with the NN of LAGs, the opinion of the majority is that such cooperation is limited and at a formal level only, with LAGs seeing little benefit from it. However, they would like to meet more and look for solutions, other activities and tools with which to help and support the development of rural areas.

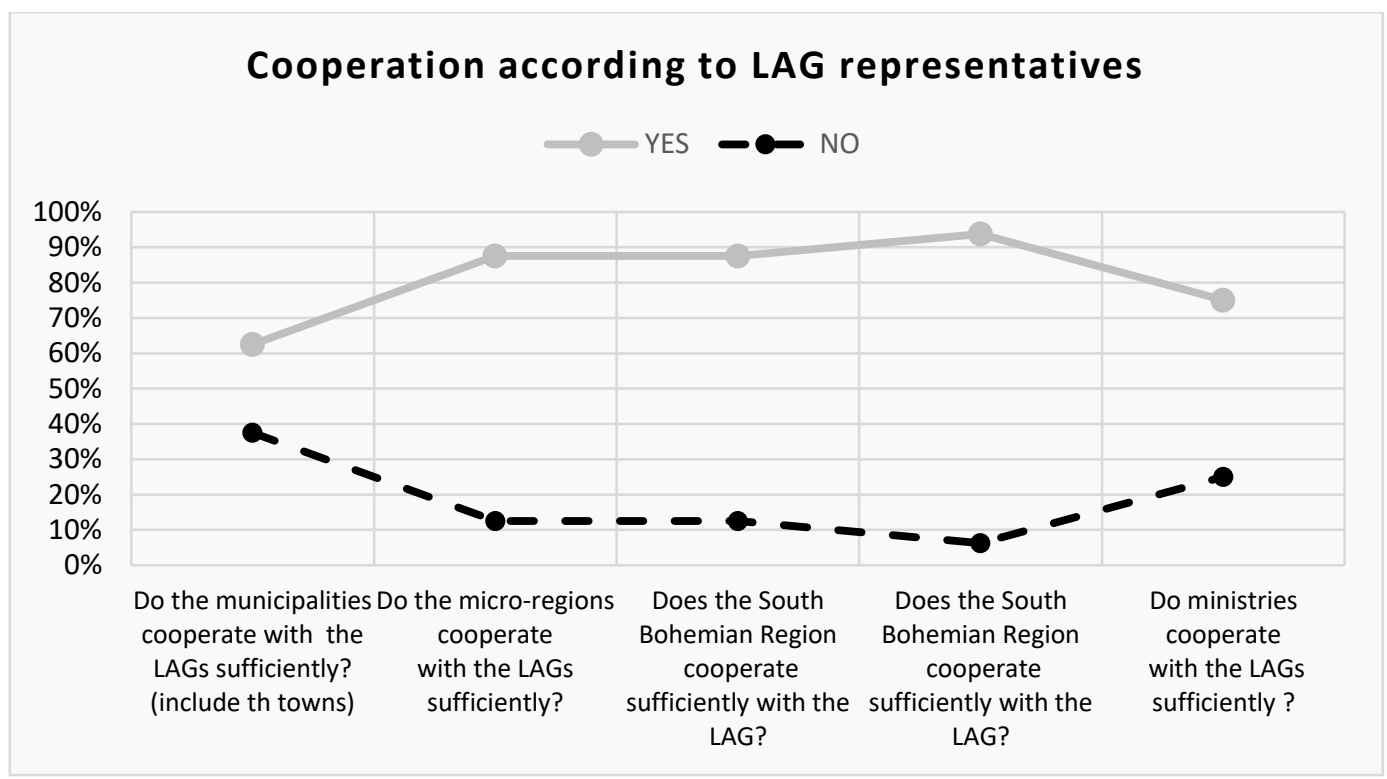

Figure 5. Cooperation according to LAG representatives

Source: Authors.

\section{Discussion}

Supported by the results, the following can be said.

At present, companies do not utilise all forms of cooperation, as was shown by the analysis of the external environment. The results of the analysis of the actors in rural areas and their influence on the business environment can be summarized as follows:

- The biggest influence on companies are competitors, suppliers, customers and business partners.

- Universities, research institutes and academies of science have the least influence on the activities of companies.

- The activities based on cooperation with LAGs are growing in intensity.

LAGs are advised to focus on the following in the foreseeable future:

- To enter into a wide-ranging discussion on the future of Czech LAGs and their position in society; improve promotion across the country; actively work and develop the Leader platform; simplify the organizational structure of LAGs.

- To involve ministries, public administration bodies in South Bohemia and experts in finding a joint solution for rural areas.

- To map the possibilities of changing the structure for the allocation of funds to LAGs (corresponding income for LAGs), related to the setting of clear rules for the redistribution thereof, the prioritization of activities and the anchoring of LAGs through legislation. 
- To prepare for the future, by defining a strategy, and where possible to introduce a single programme designed by LAGs and financed with EU funds. Today it is fragmented under different ministries Agriculture, Local Development and Labour and Social Affairs (3-4 operational programmes), etc. The current system disproportionately increases the time required for the organization of work, making the activities of LAGs more complicated.

- To inform and advise municipalities, providing support for destination management, cultural and educational events - better and more efficient redistribution of funds according to the specifics and potential of an administered area.

\section{Conclusion}

Rural areas are essentially anthropologic-ecological systems, which presupposes the harmonization of all three of its most important parts - scientific, economic and social. The interconnection and balance guarantee sustainability. The human factor plays a crucial and, in a way, regulatory role here.

In rural areas, the anthropogenic factor appears in various forms, such as a resident, entrepreneur, vacationer, tourist, conservationist, or as a member of various interest groups, communities and associations.

However, for all forms of activity in rural areas, the following principle applies: man is an integral part of nature and the countryside, neither superior nor subordinate, however unique homo sapiens are, and any wrong decision can disrupt rural equilibrium, which is a condition for its stability and sustainability.

This principle should lead actors operating in rural areas towards mutual cooperation, harmony and, if necessary, active cooperation in eliminating discrepancies.

In this area, social organizations, voluntary associations and citizens' associations have an irreplaceable place, of which LAGs play a crucial role. The citizens who permanently work in such areas know the local conditions and are the bearers of traditions and historical memories. It is therefore a pity that their irreplaceable mission in Czech rural areas is not always appreciated by the governing bodies of the state, and in some cases by the selfgoverning bodies of municipalities and the entrepreneurs operating in the countryside. As the evidence from the survey conducted in the Region of South Bohemia showed, local action groups cooperate with one another and work together at a very good level. The truth is that this is the result of their informal activities, which is also one of the principles for the proper functioning of LAGs.

The LAGs in South Bohemia would definitely like to be more involved in deciding the direction and development of the Region of South Bohemia. Such involvement is one of their priorities and is perceived by them to be their mission.

Through this contribution, the author aims to open up both public and scientific discussions on the issue, which is important for the stability of Czech rural areas.

\section{Acknowledgement}

This research was funded by the Technology Agency of the Czech Republic, ETA programme, Project Reg. No. TL01000349 - Stabilization and development of SMEs in rural areas.

\section{References}

1. OECD, The New Rural Paradigm - Policies and Governance. Paris: OECD Publishing (2006)

2. P. Rumpel, O. Slach, J. Koutský, Měkké faktory regionálního rozvoje [Soft factors of regional development]. Ostrava: Ostravská univerzita (2008)

3. M. Ambrosio-Albalá, J. Bastiaensen. The new territorial paradigm of rural development: Theoretical foundations from systems and institutional theories. Antwerp: Institute of development policy and management (2010)

4. J. Falkowski, Political accountability and governance in rural areas: Some evidence from the Pilot Programme LEADER in Poland. Journal of rural studies. 32, 70-79 (2007)

5. M. Pělucha, Teorie a realita podpory územní soudržnosti v politice rozvoje venkova $E U v \check{C} R \quad v e$ střednédobém horizontu let 2004-2013 [Theory and reality of support for territorial cohesion in the EU rural 
development policy in the Czech Republic in the medium term of 2004-2013]. Habilitační práce. Praha: NF VŠE (2015)

6. Z. Varvasovszky, R. Brugha, Stakeholder analysis. Healthpolicy and planning. 15(3), 338-45 (2000)

7. R. Perlín, A. Šimčíková, Criteria of a successful rural municipality. Europa XXI. 17, 29-43 (2008)

8. J. Binek, H. Svobodová, J. Holeček, I. Galvasová, K. Chabičovská, Synergie ve venkovském prostoru. Aktéři a nástroje rozvoje venkova [Synergies in rural areas. Actors and tools of rural development]. Brno: GaREP Publishing (2009)

9. J. Binek, H. Svobodová, J. Holeček, I. Galvasová, J. Martének, Synergie ve venkovském prostoru. Paradoxy rozvoje venkova [Synergies in rural areas. Paradoxes of rural development]. Brno: GaREP Publishing (2011)

10. J. Bernard, Individuální charakteristiky kandidátů ve volbách do zastupitelstev obcí a jejich vliv na volební výsledky [Individual characteristics of candidates in municipal elections and their influence on election results]. Sociologický časopis. 48(4), 613-640 (2012)

11. E. Hamplová, K. Provazníková, Opinion and Attitudes of Entrepreneurs of Small and Medium-Sized Business in the Czech Republic Conditions. Procedia Economics and Finance. 23, 942-947 (2015)

12. K. Knickel, H. Renting, Methodological and Conceptual Issues in the Study of Multifunctionality and Rural Development. Sociologia Ruralis. 40(4), 512-528 (2000)

13. A. Faloudi, From European Spatial Development to Territorial Cohesion Policy. Regional Studies. 40(6), 667-678 (2006)

14. R. D. Putnam, Bowling Alone: America's Declining Social Capital. Journal of Democracy. 6(1), 65-78 (1995)

15. G. Bosworth, Community-Based Entrepreneurship and Rural Development. International Journal of Entrepreneurial Behavior \& Research. Emerald Group Publishing Limited. 21(3), 501-503 (2015)

16. J. Coleman, Social Capital in the Creation of Human Capital. American Journal of Sociology. 94(1), 95-120 (1988)

17. L. Larsson. EU in the village: LEADER II, governance and rural development. In: L. Dargan, M. Shucksmith, LEADER and Innovation. Sociologia Ruralis. 48(3), 274-290 (2002)

18. R. Perlín, Představitelé veřejné správy jako aktéři lokálního rozvoje [Representatives of public administration as actors of local development]. In Problémy stabilizace venkovského osidleni $\check{C} R$. České Budějovice: Jihočeská univerzita v Českých Budějovicích, 133-151 (2000)

19. M. Woods. Rural Geography. Processes, Responses and Experiences in Rural Restructuring. London: SAGE (2005)

20. P. Pospěch, M. Delín, T. Doucha, J. Drlík, F. Nohel, D. Spěšná, Vynalézání venkova v ČR po roce 1989 [Rural invention in the Czech Republic after 1989]. Brno: Centrum pro studium demokracie a kultury (2014)

21. M. Hampl, M. Marada, Sociogeografická regionalizace Česka [Sociogeographical regionalization of the Czech Republic]. Geografie. 120(3), 397-421 (2015)

22. K. Hoggart, H. Buller. Rural development. A Geographical Perspective. New York: Routledge (2016)

23. V. Skála, Vliv sociálního kapitálu na rozvojový potenciál venkovských obcí [The influence of social capital on the development potential of rural communities]. Acta Politologica. 9(2), 40-56 (2017)

24. G. R. Gibbs, Analyzing Qualitative Data. Thousand Oaks: Sage Publications (2007)

25. R. Švaříček, K.Šed’ová, Kvalitativní výzkum v pedagogických vědách [Qualitative research in pedagogical sciences]. Praha: Portál (2007) 